\title{
Neo-Despotism as Anti-Despotism
}

\section{Bülent Diken}

What need we fear who knows it, When none can call our power to account?

(Shakespeare 1970: 923)

Today 'despotism' appears to be a marginal concept referring merely to an archaic form of government. Paradoxically, however, ours is an increasingly economized and securitized world in which the despotic imperative (do this, do that...) thrives in the shadow cast by the global politics of exception, a world in which majorities voluntarily follow manifestly despotic leaders. In this world, despotism is not only increasingly legitimated and embraced as a political 'art' but also tends to become normalized as a cult(ure). In this sense, despotic power is with us, and it is not showing any sign of disappearing soon. Thus, while we are marked by the utopian fascination with or the dystopian repulsion of the capitalist modernity, we are, at the same time, witnessing the persistent revival of archaic forms of rule and togetherness, of 'retrotopias' (Bauman 2017). These two poles, 'futurism' and 'archaism,' as Deleuze and Guattari called them, can neither be united nor separated; if the society tries to 'hold on to the one,' it flows 'through the other' (1983: 280). 
In the article I use the concept of despotism to express the archaic pole of this problematical oscillation.

In its most archaic sense, despotism originates in the command, in an imperative bent on capturing, dominating and enslavement. Power is basically a capacity to give orders. And an order always manufactures obedience and initiates an action (Agamben 2019: 48). Beneath every command, there is a disjunctive bio-political relation: the strong commands, feeding upon the crowd it itself generates through fear, and the prey seeks a line of flight, terrorized by the fear of being captured (Canetti 1962: 304). As such, as something that seems to be inherited from our animal past, the despotic command is 'the most dangerous element' in human sociality (Ibid. 333). The command designates the transgression of the distinction between law and unlaw, and thus the perversion of politics.However, I am not interested in despotism merely as an empirical phenomenon. I treat despotism as an idea, as a virtual concept, that cannot be reduced to its actual historical forms. Despotism, in other words, is a metaphysical problem that cannot fully actualize itself in concrete situations. While actual despotisms, classical, early modern or late modern, seek to suspend the law in one way or another through off-scene/obscene technologies of deception, and to administer fears and hopes through de-politicization, they do so differently on each occasion. And this differentiation is, I will argue, not reducible to a difference between, for instance, classical tyranny and modern totalitarianism.

I define despotism initially as arbitrary rule, in terms of the transgression of the distinction between law and unlaw. As such, the concept signifies the perversion of politics, the monstrous outcome of an internal distortion whose seeds always reside in the actual historical situation. However, I deal with despotism not as a solipsistic undertaking but as part of a nexus that always already contains two other elements: economy and voluntary servitude. If there is one thing that unites the 
historical and contemporary forms of despotism, it is the fact that despotism is a relation; it is an articulation of the despotic will to capture with de-politicization (economy) and with a technology of deception that aims at manufacturing consent (voluntary servitude). The 'despot,' whether it comes in the shape of a person, a structure or a technology, can only exist in this nexus. The transformations and constellations of despotism are bound up with the transformations of this nexus. I give three different - ancient, early modern and late modern - accounts of this nexus, demonstrating how despotism and its uses continuously take on new appearances. I also emphasize, in a counter-classical prism, how the classical nexus has evolved in modernity while the focus gradually shifted towards another triangulation: neo-despotism, use and dissent. This new triangulation is not identical but allied with the classical one. Precisely therefore it produces differences that are significant in relation to any discussion of despotism today.

Crucially, what holds the nexus together, both in its classical and contemporary versions, are apparatuses of capture. Despotic power only rules and controls what it can capture (Deleuze and Guattari 1987: 424). To use a metaphor from Kafka (2015: 16), despotic power is like 'a cage' that goes 'in search of a bird.' But the despotic imperative does not only capture, it also opens up a space for lines of flight (Deleuze and Guattari 1987: 448). Indeed, the transformations of despotism derive from such escape, from the internal tendency of despotism to deterritorialize. Historically, the despotic machine has first emerged in the Orient as a model of generalized (public) slavery (Ibid. 451). Later, the despotic rule took a new form in ancient Greece as the slave became a private property as with other economic elements of the oikos, the private domain, which the Greek sought to hold separate from the polis, the domain of politics. But the relationship between the oikos and the polis has always been a problem, and this problem is the starting point of my discussions. 
I open with discussing the ancient Greek understanding of despotism as perversion. Here I focus on Plato, Aristotle and Xenophon, illuminating how their attempts at reforming despotism intimate interesting paradoxes that have contemporary relevance. Then I discuss the slave as a biopolitical figure that problematizes the political relationship between the polis and the oikos. The concept of use, a central concept for the article, is also introduced here. Next, I discuss despotism in the prism of the early modern political philosophy. Here the focus is on Machiavelli and Hobbes. Initially I elaborate on the relationship between despotism and the accentuation of operational effectiveness in Machiavelli. I go on to emphasize the role of free will in Machiavelli and its origin in economic theology. Then I turn to Hobbes, focusing on the Hobbesian contract and the fear of dissent which it seeks to handle. The Leviathan appears, in this light, as a despot who promises to save us from other despots. But who is going to save us from the Leviathan? This question invites a discussion of Spinoza, the philosopher of anti-despotism par excellence. Following this, I take the discussion of despotism, economy and voluntary servitude into late modernity by focusing on Arendt, Schmitt and Agamben's political philosophies as well as their implications for the critique of despotism. To start with, I elaborate on Arendt's conception of totalitarianism. In contrast to Arendt, however, I underline the continuities between ancient despotism and modern totalitarianism. The pivotal concept in this regard is bio-politics. Then I examine the way in which Schmitt's theory of exception is formed by the fear of dissent, which is the leitmotiv of his desire to capture anomiecivil war, disagreement, revolution... - within the domain of the state. I outline the spectral role of the concept of despotism in this endeavor. In this context I turn to Agamben's political theory, reading it as a critique of despotism. Following this, I present my own conception of neo-despotism as a paradoxical form of despotism that misrecognizes itself as a democratic structure. Finally, I consider the main contours of what might be called anti-despotism in late modernity and re- 
elaborate on use as a key concept in this context, illuminating the link between despotism and the two antagonistic senses of use, free use and instrumental use. ${ }^{i}$

\section{The Ancient: Despotism of the Oikos}

The ancient Athenian thought related the concept of despotism to perversion, distortion, and corruption. Plato (2003), for instance, defines despotism as a perverted form of democracy. When, with a populist gesture, democracy sweeps the principles of good government away, it passes into

tyranny $(8: 562 a) .{ }^{\text {ii }}$ The people see the monster they have created at one point, but this is always a sign that it is too late (8:569b). For Aristotle (1995, 3:1279b4), too, despotism is a perversion. While kingship is a 'true' form of government based on the common interest, tyranny, in contrast, is based on the interests of a violent usurper, the tyrant (Aristotle 1995, 4:1295a). Importantly, tyranny is a form of rule exercised over 'unwilling subjects' (Ibid. 4:1295a). Thus it can only be sustained through blatant terror or reform, through 'making it more like kingship' (Ibid. 5:1314a29). Playing the king, the despot must become a vanishing mediator on the way to kingship as 'true' mode of governance. Xenophon, too, understands despotism as distinct from kingship. But in contrast to Plato and Aristotle, however, he does not immediately condemn it as a perverted, illegitimate regime. In his treatise Hiero, for instance, Xenophon (2013) recognizes its unhealthy aspects but seeks to reform despotism as despotism, without transforming it into another, better political regime. In this, crucially, the focus is on economy. The reformed despot is an economist. In ancient Athens, the rule of the despot, oeconomicus, denoted a specific power relation in the oikos, the domestic sphere. Political power, in contrast, was seen as something that pertains to the polis, as a relationship between free men concerning the common good. The presence of the slave 
in the oikos means that oeconomicus cannot be political. The despot is an apolitical figure. Yet, according to Aristotle, for instance, a specific form of knowledge pertains to the master: 'the master must simply know how to command what the slave must know how to do' (Aristotle 1995: 7.1255b). But Plato denies its possibility. According to him, the knowledge that belongs to the master can be subsumed under abstract conceptual, philosophical knowledge. Consequently, a household is comparable to a state; they do not differ 'as far as their government is concerned' (Plato 2010: 259b). Likewise, Xenophon's Socrates teaches that the management of the polis and that of the oikos are similar. However, unlike Plato, Xenophon does not allow for the direct control of the oikos by the polis. On the contrary, he lets the oikos become a model for, if not colonize, the polis. Hence the advice to the despot in Hiero, 'account the fatherland your estate' (Xenophon $(2013,11.14)$.

Significantly, this tension between politics and economy is internalized within economy as a question of the cherrematistike, the art of making money. Plato, in this context, considers 'acquisitiveness', a characteristic aspect of the chèrematistikē, a significant factor in political perversion (Plato 2003, 8: 555b). Aristotle, too, makes an effort in Politics (1995, 1:8-9) to differentiate between economy and the chêrematistikē, between the 'natural' form of acquisition, which consists in attaining 'true wealth,' property or goods that are necessary for the life of the household or the state, on the one hand, and the 'unnatural' form of acquisition, which consists in selfish profit gain, on the other. As Marx (1976: 252) articulates it, the logic in the first case operates in the form of C-M-C: commodity is sold for money to buy another commodity. In the second, 'unnatural' case, however, one is concerned solely with money. Now money becomes both the beginning and the end of the process of exchange. The problem is that, despite the differentiation, there is an overlap between the two forms, between 'economy' and the 
'chrematistic' principle. As Aristotle (1995, 1:1256b.40) admits, the two modes are 'not identical yet ... not far removed.' It is as if what is 'unnatural' is always already at the heart of 'natural' economy and has a potential to become the ultimate aim of economy. The problem is equally unsettled in Xenophon. Hence his economist Ischomachos buys 'inactive land' and improves it only with a view of selling it for profit (Xenophon 1998, 20:26).

We have so far two perversions, of economy into chrematistics and of kingship into despotism. But what if despotism is not really an extreme perversion but rather the truth of kingship? And what if chrematistics is not merely an 'unnatural' deviation from an economy based on 'natural' use-value production but the truth of economy as such? To entertain these ideas, let us now turn to the relationship between the despot and the slave. Aristotle justifies the abandonment of the slave from politics with reference to the concept of use (Agamben 2015a: 5; see also Aristotle 1995, 1:1254b.16-27). The master uses the (body of the) slave as an instrument, as an extension of his own body. The Aristotelian definition of use, however, introduces a differentiation. It divides use into dynamis and energeia, potential and act, while the pivotal focus of the distinction shifts onto the passage from potential to act, a passage secured by habit (Agamben 2015a: 50). The problem here is that use precedes the division of potential and act. Being-in-use is irreducible to being-in-act; a potential does not automatically pass into the act or is put into work (Ibid. 58). One can have the habit in an inoperative state, without it producing any effects. A piano player, for instance, is not merely the master of the potential to play the piano but constitutes herself or himself as making use of one's self as well as the piano insofar as she or he plays and knows habitually how to play. Use in this sense is not a virtue of a hexis (in Greek) or habitus (in Latin) that converts potential into praxis but something ontologically given, an inoperative praxis that can emerge only through a deactivation of the potential-act apparatus that posits the primacy of act over potential 
(Ibid. 81). It is a principle that precludes the disappearance of potential into the act (Ibid. 93). Slavery, in this prism, expresses the capture of use by despotic-economic power, the transformation of the human into an 'instrument-human' (Ibid. 78). At the same time, however, the slave is an 'animal-human,' a merely biological being with no political rights, which allows for the opening up of a political space. The simultaneous exclusion and inclusion of the bare life of the slave is the foundation of politics (Ibid. 263).

Consequently, one can say that there are not two 'arts' that can be neatly distinguished from one another, one despotic and one kingly, but two distinct but inter-related languages to describe the same network of power, in which despotic power and kingly power both repel and attract each other. In this sense, the figure of the slave compels one to reformulate the relationship between the king and the despot, between the polis and the oikos. Through the slave, the despotic relation surfaces as the hidden core of all Greek politics, the primary referent of which is the instrumentalized bare life.

Crucially, however, the Greek distinction between potential and act does not leave the 'citizen' of the polis unaffected. The distinction re-enters the city, opening another divide among the free citizens themselves. Consider Plato's Republic, which seeks, while assuming the existence of slaves, to outline how justice can be realized in a state of free citizens. What is decisive is the principle behind the division of labour: the one person-one function principle, which requires that we forbid 'our shoemaker to try his hand at farming or weaving or building and told him to stick to his last' (Plato 2003, 2:2.374b). Plato's republic is founded on an economic principle, needs, justified with reference to the difference of nature among the citizens and thus the necessity of division of labor. What enables this differentiation is use, more specifically the use of time. As Rancière (2003: 3-7) draws attention to, what is really at issue here is not the time for work as such 
(work, after all, is the ergon of the slave) but rather the time for leisure that delineates the degree to which one can be exempted from the use of the body for the sake of necessity. In this sense, the absence of time to engage with the useless (philosophy, politics and art) grounds in ancient Athens not only the exclusion of the slave but also social differentiation and domination (Ibid. 13-14). In this sense, the distinction between the animal and the human (as 'speaking animal' or as 'political animal') is ultimately an order of use, a decision on what is common and not common in the polis. By the same token, the problem of despotism is always already related to another problem, maintaining a social order which is also an order of use.

\section{The Early Modern: Despotism of the Polis}

In Discourses, Machiavelli condemns despotism for it is not compatible with freedom and the common good (Machiavelli 1999, 2:2). However, the despot returns as a reformed despot in The Prince (Machiavelli 2015). Here Machiavelli claims that successful rulers owe nothing to fortune except 'opportunity,' which brings them 'the material to mold into the form which seemed best to them' (Machiavelli 2015: VI). Ruling, in other words, is poiesis. A good ruler is one who can form both the society and himself on the basis of his free will, beyond the concerns of morality. The ancients had insisted on happiness as the primary purpose of political action and on virtue as a transcendent yardstick for such action. But for Machiavelli virtue must bring with pragmatic effects, rewards. 'Hence it is necessary for a prince ... to know how to do wrong, and to make use of it or not according to necessity' (Ibid. XV).

But what precisely should we understand from 'effect,' 'poiesis,' 'necessity' and 'to do wrong' here? In Machiavelli, effect is the only measure of action. We must note here that already before 
Machiavelli effectiveness, effectus, had become a central concern for the Christian liturgy. That potential must be realized or brought into an effect is a characteristic assumption of the Christian paradigm of effectiveness, according to which 'virtue' has the goal of attaining the 'good' (Agamben 2013b: 100-101). The measure of virtue is its effectiveness, its being rendered operative. Consequently, virtue ceases to be an end in itself and effect becomes autonomous. As such, effectus is the key to understand what Machiavelli means by effective government. What is at issue in effective government is rendering effective a potential. The prince is the external operator of this realization. Thus his activity is intimately related to poiesis, the art of giving form to material. The art of politics in Machiavelli is a form of poiesis insofar as it produces a concrete work or goal, security. But it is also a form of praxis insofar as it is the execution of an art. That is, the field of action specific to Machiavelli's prince is as much political strategy as security. Hence his ruthlessly instrumental logic, which dictates that a prince must 'know how to do wrong.' His actions must be judged not by extra-political, i.e. ethical or philosophical, standards but by their practical consequences. An action, that is, is good only insofar as other people praise it (Machiavelli 2015: XV). Opinion, the spectacle, says the last word on action. Thus it is vital for a prince to 'appear to have' virtue (Ibid. XVIII). The prince's rise or fall depends on his ability effectively to align his subjects to his own interests, even if this entails obtaining their consent 'by payments' (XVII).

Herein lies the prince's economic paradox, too: he must account his country as his oikos, but this should not provoke hatred (Ibid. XVII). What is displaced through this paradox is the Socratic concern with friendship or love as a yardstick for the relationship between the ruler and the ruled and for a possible reform of despotism. Consequently, force, and thus fear, become indispensable to the governmental apparatus. The prince, in turn, fears two prospects: external threats, war, and 
internal insurrection, that is, dissent or people's hatred (Ibid. XIX). In dealing with these threats, the prince should be able to use extraordinary methods, force as well as the law, if and when necessary (Ibid. XVIII). That is, 'necessity' might dictate breaking the law (see Machiavelli 1999, 1:34). Thus, the modern absolutist state envisaged in The Prince, in which the order is 'dictated' without the consent of the people, borders on despotism. This tendency peaks in Hobbes' Leviathan.Hobbes completed what Machiavelli initiated: the movement of the despot from the oikos to the polis. What we have in Hobbes, as in Machiavelli, is a despotism of the polis. Neither the Prince nor the Leviathan are a Hiero-style, self-aggrandizing despot concerned solely with his own private enjoyment and gain. Their primary concern is the security of the state. However, the Leviathan goes one step further and embarks upon the task of governing the population while securing the state. The Leviathan's primary task is to create obedient subjects. Leviathan, too, must govern, control and, when necessary, repress human passions through fear. Thus Hobbes needs the state of nature as a spectacle of fear in which life is 'solitary, poor, raw, brutal and short' (Hobbes 1991a: 89). It is because they fear the insecurity of this condition, individuals decide to transfer their natural right to the Leviathan. In this sense Hobbes' state is, like Machiavelli's, a state which has security as its raison d'etre. And remarkably, the transfer of individual rights to the Leviathan must be complete. The subjects must fully transfer not only their natural right to use violence but also their natural right to interpret, their freedom of thought and speech, to the Leviathan (Ibid. 120; Schmitt 2014: 17). An incomplete transfer would mean the persistence of the danger of civil war, which, according to Hobbes, 'proceeds from controversy' (Hobbes 1999: 113). In other words, the full transfer means that the 'people' exist only momentarily, disappearing into a multitude at the moment they decide on the sovereign (Agamben 2015b: 35). As such, without dissent and without the 'people,' Hobbes's societal condition is emptied out of politics, while at 
the same the privatization of the citizenry brings with it a radical intervention into the private sphere through the monopoly of interpretation.

However, Hobbes's state of nature must not be understood as a chronological period preceding the formation of the city. As is the case with civil war, the society always risks falling back upon the state of nature (Hobbes 2007). What matters primarily in Hobbes is not the state as an aggregation of wills, manifested in a contract, but the state's monopoly of violence and, more importantly, its capacity to suspend the law in exceptional times. The root of Leviathan's sovereignty is grounded not in founding the law but in the capacity to suspend it, in exception (Agamben 1998: 64). Consequently, in the state of exception, as in civil war, there re-emerges a zone of indistinction between the societal condition and the state of nature. In Hobbes, civil war designates a moment of politicization (of the oikos) and the de-politicization or economization (of the polis) at once (see Agamben 2015b: 12). In this, the consent provided by the contract does not exclude but rather justify the despotic imperative.

Let us focus, against this background, on the difference between ancient despot and the Leviathan. The ancients assume that passions such as egotism and hostility are part of human nature, that they cannot be eradicated. Thus despotism can appear to them only as a perverted extension of a natural desire for honor, power, which, although it cannot be extinguished, can be sublimated or reformed in a properly political context. But Hobbes no longer assumes that the despotic desire can be reformed. For Hobbes, despotism can only be extinguished. He assumes that once the order of the Leviathan grants its subjects security and welfare, once their basic desire for self-preservation is satisfied by keeping their fear of death at bay, the foundation for their potential aggressions, too, will wither away (Newell 2013: 496). In a sense, therefore, the Leviathan is a despot designed to save us from despotism (of the passions characteristic of the state of nature). 
What is original in Hobbes is that he turned fear in general (anxiety associated with the state of nature) into the fear of the sovereign state. The despotism of all versus the despotism of the one. And as with other despots, what is most frightening to the Leviathan is the possibility that the demos takes it upon itself the right to interpret what is just and unjust. In order to pre-empt that possibility, the demos must be governed. Hence Hobbes' Leviathan is also a precursor to governmentality. Unlike Machiavelli's Prince, the Leviathan is not simply interested in the control of territory but also in controlling the population (See Pocock 2016 and Vatter 2014). The Leviathan's primary aspiration is governing its subjects, administering the relation between the state and the people, and manufacturing consent. Importantly in this regard, the state of nature is overcome only when everybody voluntarily surrenders their power to the sovereign. Nietzsche (1974: 53) argues that the notion of 'free will' is 'fabricated' by monotheistic religions to make humanity 'accountable' to a transcendent God. One cannot sin without free will. Similarly, in Hobbes's political discourse, the free will indicates inclusion in the sphere of the law, rendering the individuals responsible to the Leviathan. This is why the critique of despotism is intimately linked with the critique of free will.

Spinoza, Hobbes's contemporary, articulates such a critique and does so without recourse to despotism. Consider the way he sets up free use against free will, while democratic government becomes an alternative to despotism. Insofar as the defining characteristic of the despotic desire is the distribution of use, determining what to consent to or not, free use which Spinoza associates with democracy necessarily involves the de-activation of the despotic distribution of use. And so, the problem shifts from free will to use, which is the step foreclosed in Machiavelli and Hobbes. The meaning of 'use' in Spinoza is threefold, referring to the use of the body, to the use of others (society) and to the use of God or nature. Regarding the first, Spinoza postulates that each individual should seek what is 'truly useful' for himself (1993: 152). The more pleasure one is affected by, the more one participates in the divine nature (Ibid. 193). However, such perfection is 
extremely difficult to attain alone. Co-operation is necessary. Therefore, secondly, 'there is ... nothing more useful to man than man' (Ibid. 153). And thirdly, the use of God or nature is linked to self-contentment, the pleasure associated with one's contemplation of oneself and one's power of acting (Ibid. 173). If our actions indicate our power, that is, our reason, and passions the lack thereof, it is 'extremely useful in life' to perfect our intellect as much as possible. Consequently, happiness or blessedness is not 'the reward of virtue, but virtue itself' (Ibid. 218).

The ancients, especially Xenophon, had sought ways to reconcile virtue with politics and economy. The early moderns, especially Machiavelli, reacted to this by removing virtue from the political and economic agenda. Spinoza seeks to put virtue back in its place. One with wisdom, with the power of reason, is more capable of using one's body, one's society and God or nature than an ignorant person who is more easily agitated by external causes. Ignorance is that which turns use into abuse, joy into sadness, and freedom into despotism. Concomitantly, despotism is the solitude of the sad, the sadness of the person who cannot engage in free use. In this way, Spinoza's immanent democracy negates the despotic imperative, which can only emerge on the basis of passive emotions, especially fear. However, democratic sovereignty must be absolute. Democracy cannot tolerate the enemies of democracy (Spinoza 1951b: 304). But while in Machiavelli and Hobbes the 'absolute' leads to direct securitization and thereby de-politicization, Spinoza's 'absolute' democracy seeks politicization, including the possibility of dissensus (see Spinoza 1951a: 143). In Marx's formulation that embraces Spinoza's, 'democracy is the resolved mystery of all constitutions' (Marx 1970: 29-30). While other forms of government can be 'perfected' towards democracy, democracy itself can only be corrupted or perverted towards other forms of governments, ultimately into despotism. 


\section{The Late Modern: Neo-Despotism of the Exception}

In late modernity, the problem of despotism resurfaced in relation to fascism and the Holocaust. Arendt, who identifies the despotic imperative with 'totalitarianism' (1973), is the most central theorist in this context. Though, for Arendt, totalitarianism is not merely more of the same, an eclectic assemblage that borrows its methods from tyranny, despotism and dictatorship, but an 'entirely new form of government' (Ibid. 461, 478). Totalitarianism is essentially a politics of speed, a 'movement,' which consists in applying an idea, an ideology, to history with the aim of setting a 'process' into motion (Ibid. 463, 468). Hence total terror, designed to extinguish what hinders the process, is the 'essence' of totalitarian rule (Ibid. 465-7). But the paradox of totalitarianism is that it exists in a non-totalizable world (Arendt 1973: 342). Hence it needs the totalitarian spectacle, which is grounded in a passion to totalize what is impossible to totalize, to create 'a perfect world of appearances' (Ibid. 353). The Nazi did not seek verification in 'reality' but in the camps, the 'laboratories' where 'everything is possible' (Ibid. 437). Arendt insists in this context that the Nazi did not have a utilitarian approach to economy and politics. In Nazism, even the human being itself has lost all intrinsic value. The camp, as the managerial ideal of the Nazi totalitarianism, is a symbol of this anti-utilitarianism (Arendt 1973: 438; 1994: 233). Herein lies too, according to Arendt, a significant difference between classical despotism and modern totalitarianism. Another difference concerns the relationship between the public and the private: while despotism is a tendency toward reducing the polis to an oikos, totalitarianism signifies the 'abolition of the private sphere' altogether, positing the identity of public and private interests (Arendt 1973: 432).

In The Human Condition, however, Arendt considers modernity in terms of the growth of the private realm 'and the modelling of all human relationships upon the example of the household' 
(1958: 35). Hence the elevation of 'life itself,' biological life, to the level of the highest value in modernity (Ibid. 322). Yet Arendt does not bring this interest in bio-politics together with her analysis of totalitarianism (Agamben 1998: 4). Instead, she insists that the answer to totalitarianism must be political in the ancient Greek sense, as the appearance of the citizen on the public stage (1973: 53-5). But the persistence of biopolitics in modernity suggests the impossibility of (re)differentiating the polis and the oikos. Bare life cannot be simply referred back to the oikos (see Agamben 1998; Diken and Laustsen 2005). At any rate, the politicization of bare life, a decisive tendency of Greek politics that is exacerbated in modernity, establishes, contra Arendt, a significant continuity between the concepts such of despotism and totalitarianism. It goes without saying that a similar case of continuity can be made regarding the spectacle, which is already an intrinsic element of classical despotism. Further, the reduction of the 'enemy' to life unworthy of living, to bare life, is, again, specific neither to totalitarianism nor to the twentieth century camps. Denying existence to the enemy is a defining element of despotism, both ancient and modern. Also, for Arendt, the attempt at eliminating action from the political sphere always signals a despotic-totalitarian tendency, threatening to inject a model of government based on the command (which pertains to the oikos) into the polis. However, not all critique of action implies a will to substitute action with governance, with economy. What is decisive is the question of whether the paradigm of politics should be action or de-activation, potentiality or impotentiality, efficient use or free use. Finally, regarding the 'non-utilitarian' aspect of the camps, one could claim that the Nazi ideology is rather ultra-utilitarian insofar as it involves the total instrumentalization and selfinstrumentalization of human beings (see Žižek 2001: 112).

Let us, at this point, turn to one of Arendt's contemporaries, Schmitt. Schmitt's theory of sovereignty, which valorizes dictatorship and expresses an unmediated fascination by a bio- 
political power, is pivotal for any discussion of despotism in late modernity. Schmitt is to late modern conservatism what Hobbes is to the early modern. He is keen on emphasizing that Hobbes's state of nature is an ever-existing potentiality that can resurface at any time in the form of civil war, as dissent and chaos. This re-occurrence of nature within society is the necessary background for his conception of sovereignty as a capacity to suspend the law. The sovereign is the one who decides over the state of exception (Schmitt 1985: 5). As such, the theory of the state of exception frames Schmitt's answer to what he sees as a 'completely new' danger facing the post-absolutist modernity, 'the political organisation of the proletariat' (Schmitt 2014: 179). Marx and Engels' 1848 Manifesto depicts a purely antagonistic world determined by class struggle, an international civil war, in which all the proletarians of the world are called to unite against international capital. Further, the appearance of the proletariat coincided with the re-appearance of dictatorship as a Leftist demand, the 'dictatorship of the proletariat,' along with the modern concept of revolution. Schmitt's basic thesis in this respect is that the classic form of war, war between states, is metamorphosing in late modernity into an international civil war. Thus the partisan becomes an ersatz figure of sovereignty who can reiterate the friend-enemy distinction instead of the state (Schmitt 2004). In its origin, the partisan designates a politically committed, mobile, 'irregular' fighter defending a territory against an enemy soldier in uniform (Schmitt 2004: 21-6). Significantly, however, after the first world war the defensive partisan who fights for a soil has given way to a new figure: the revolutionary. The revolutionary is an 'aggressive' political figure who has an 'international' agenda rather than defending a territory (Ibid. 35). Schmitt saw this figure incarnated in Marxism, particularly in Lenin, who, in a properly Machiavellian manner, recognized that the partisan war is a means to an end, the international revolution, and whatever 
works to this end is legitimate, regardless of whether it is legal or illegal, peaceful or violent, just or unjust (Ibid. 55).

Insofar as revolution is a concept of modernity, which is linked to the development and analysis of capitalism, one could say that Schmitt seeks to capture the idea of revolution, the idea of the 'dictatorship of the proletariat,' inscribing the violence that pertains to it in the domain of state power as constituent power. It is therefore that Schmitt (2004) draws a parallel between dictatorship and the state of exception. This move, however, is problematical for, in contrast to Schmitt's understanding of dictatorship, the state of exception is a space of 'anomie' without legal determinations (Agamben 2005: 51). What is necessary is to de-activate it, to expose its central fiction by showing that there is no considerable link between life and norm, between violence and law, that the only possible 'relation' between them is one articulated through violence. What is necessary, in other words, is trying to think of politics in terms of a 'destituent power,' which cannot be captured by the dialectic of anomie and norm, that is, by the logic of the state of exception (Agamben 2013a). For the idea of freedom can only be grounded in impotentiality:

To be free is not simply to have the power to do this or that thing, nor is it simply to have the power to refuse to do this or that thing. To be free is ... to be capable of one's own impotentiality, to be in relation to one's own privation. This is why freedom is freedom for both good and evil. (Agamben 1999: 183)

Human life always maintains a potentiality. And insofar as all potentiality is also impotentiality, no mode of life, no living being, can be defined independently of inoperativity, through which it organizes itself as a form-of-life (Agamben 2015a: 247). The form-of-life is the habitual use of this potential (Ibid. 207). As such, use signals the possibility of another conception of human praxis as a kind of ontological communism (see Ibid. 94). What counts in this organization is no longer 
instrumental use or sovereign subjects endowed with free will but 'anonymous' human beings who seek to constitute themselves as form-of-life through inoperativity (Ibid. 247).

\section{Politics of Security as Neo-Despotism}

Let us, at this point, turn to theory construction and focus on the contemporary society in the perspective of despotism. I want to introduce the concept of neo-despotism in this context. First a few words on exception. The theory of exception draws attention to a stubborn but obscure trend of all times, a despotic tendency that has shaped the Western politics in the past and is powerful enough to frame and structure its future if allowed to unravel uncritically. Ours is a society characterized by the increasing promotion of the logic of exception from the periphery of social life to its center, a society in which the abnormal shows all the signs of turning into a norm. A world, in which 'the state of exception has ... reached its maximum worldwide deployment' (Agamben 2005: 87). But generating emergency means generating fear. Concomitantly, today fear is not an exceptional state but an 'environment' (Virilio 2002: 15). Yet, the contemporary state of exception is not formally declared. Rather, it remains a 'fictitious' state which is justified with reference to vague non-juridical notions such as 'security reasons' and, unlike the conventional sense of the state of exception, does not identify a clear and distinct enemy (Agamben 2013a). In this sense the paradigm of exception is not sufficient in itself to understand the contemporary governmentality, the axiom of which is governing the effects rather than the causes, problem management rather than problem solving (Ibid.). It might be helpful, in this context, to think of the politics of security in terms of despotism, or rather, as neo-despotism. 
The constitutive feature of neo-despotism is self-denial: unlike its conventional incarnations, today's despotism can appear as its opposite, staging itself as a domain of freedoms. Neodespotism speaks the language of fear, of security, but does not seek to legitimize a despotic order per se. On the contrary, it promises a new, 'democratic' world free from 'despots' and their 'terror.' Everything in neo-despotism hinges on a specific form of political subjectivity, which Badiou (2009: 59) has called 'obscure subject,' a reactionary subject in the guise of a new, eventful subject. In this sense, neo-despotism is a despotism that has 'learned' from, or rather appropriated, the past criticisms of despotism. As such, despotism is always neo-despotism, designating not merely an external force but a strategic field of formation in which the struggle revolves around appropriating ideas and principles by emptying out their content. 'The Devil's most skilful trick,' writes Baudelaire in Paris Spleen (2010: 61), 'is to convince you he doesn't exist.' Neo-despotism is despotism that has perfected this trick. Thus it betrays politics by performing itself as an oxymoron, as an anti-despotic despotism. Or, by the same token, as an anti-democratic democracy, which, as Rancière (2006) has pointed out, scorns democracy every time it surfaces in the West while it seeks to 'bring democracy' by force abroad.

Despotism has hitherto been defined as a relation to unlaw, as the forcing of limits of the law. Which suggests that there is a limit, that the norm and the exception are distinguishable. Neodespotism, on this account, is despotism without limits. It articulates itself in the horizon of a culture of exception in which exception is the rule. Thus it is a despotism which no longer recognizes itself as despotism, and thus no longer seeks to dissimulate itself. This is why, even though despotism has always been a riddle for thought, neo-despotism can present itself as an antiriddle, a riddle that denies its own solution. It does everything despotism does but it cannot be named as such. Much of what Trump says, for instance, consists in blatant lies. Despite this, 
however, he can ride on a myth of truth-telling. Hence the widespread perception that Trump speaks openly where others don't dare to voice their opinions. This is why Trump is inauspiciously 'compared to a man who noisily defecates in the corner of a room in which a high-class drinking party is going on' (Žižek 2017: 254; referring to Mitchell 2015). It is thus tempting to go further and compare Trump to another, true truth-teller, Diogenes, who was famous for his literal acts of masturbating in the agora and defecating in the theatre. What is the difference between Trump and Diogenes? Diogenes was the master of the art of truth-telling, parrhesia (see Foucault 2001: 19). Trump, in turn, stands in for the total emptying out of truth-telling as a political and ethical praxis. Milan Kundera has once described 'kitsch' as a 'dictatorship,' as a despotic world 'in which shit is denied and everyone acts as though it did not exist' $(2000: 242,245)$. Thus, from Diogenes to Nietzsche, thought has always made use of shit as an exceptional weapon against powers to be. With Trump as a neo-despotic figure, however, we are witnessing the becoming rule of the exception, of the appropriation of shit by the neo-despotic discourse, its banalization as business as usual. ${ }^{\mathrm{iii}}$ In the age of post-truth, in other words, the problem is not that excrement enters the public scene but that everything else is drowned in it.

When a man wears a wig, he usually tries to make it look like it's real hair. Trump achieved the opposite: he made his real hair look like a wig; and maybe this reversal provides a succinct formulation of the Trump phenomenon. At the most elementary level, he is not trying to sell us his crazy ideological fictions as reality - what he is really trying to sell us is his own vulgar reality as a beautiful dream. (Žižek 2017: 260)

We know from the ancients that, when a democratic society falls under the influence of bad leaders, who intoxicate it with the pleasures of excess, democracy passes into despotism. Surely, in this process populism plays a significant role. But with Trump we seem to be confronted with a new, 
post-political version of populism. Insofar as politics is politicization, post-politics signifies the foreclosure of politics. Interestingly, in this sense, as technocratic consensus politics, Trump would seem to be a reaction against post-politics. Yet, he is post-political in another way. The state machine is for Trump an oikos. As such, perhaps Trump is merely an alibi, the anchor of our neodespotic reality today. Just as the real function of Disneyland is, as Baudrillard (2005: 124-5) argued, to hide the fact that the rest of America is fake, Trump as a ridiculous despot is what enables us today to sustain the fantasy that our politics is serious and well-grounded except, that is, Trump exists (see Diken \& Laustsen 2017).

Who is the real despot in today's post-truth world, then? Newell, an established academic on ancient political philosophy, provides a flawed but telling answer. In his recent work (2013), he offers a three-fold taxonomy of the figure of the tyrant. The first is the classical, thief-like, selfaggrandizing tyrant who seeks profit at the expense of the common good. The second type is more ambivalent: the benevolent despot, the 'reformer' who can put absolute rule in the service of the society (Ibid. 437). And third, and as a specific outgrowth of the Machiavellian and Hobbesian political theory, a new figure of despotism, which first appeared with the Jacobin terror and then quickly evolved into a pattern: modern totalitarian revolutionary ideologies ranging from Bolshevism, Nazism, Maoism ... and finally Al Qaida and ISIS. In short, everything that does not fit Newell's own political conviction. Just as the distinction between 'kingship' and 'despotism' enabled the ancient Athenians to disavow the despotic kernel of kingship itself, Newell's distinction distances today's (neo)liberal democracy from its own dark history and present. Sacha Baron Cohen's film The Dictator (2012) satirizes this view in a scene where the dictator (a 'terrorist tyrant' in Newell's terminology) asks: 
Why are you guys so anti-dictator? Imagine if America was a dictatorship. You could let $1 \%$ of the people have all the nation's wealth. You could help your rich friends get richer by cutting their taxes and bailing them out when they gamble and lose. You could ignore the needs of the poor for health and education. Your media would appear free but would secretly be controlled by one person and his family. You could wiretap phones, you could torture foreign prisoners. You could have rigged elections. You could lie about why you go to war. You could fill your prisons with one particular racial group and no one would complain! You could use the media to scare the people into supporting policies that are against their interests. I know this is hard for you Americans to imagine, but please try.

\section{The neo-despotic command, use and the free will}

Neither Hiero nor The Prince nor Leviathan called their protagonists despots, but they knew, as their audiences did, that they were. While keeping silent about this, it did not occur to them to redress themselves as anti-despots. But insofar as it disseminates revised concepts, obscuring their content, neo-despotism must appear in the guise of its opposite, as a domain of freedom and choice. To make sense of what is at stake here, we must reflect on the nature of the command. In the Western though, there are two distinct but related ontologies that remain in a disjunctive relation: the ontology of declaratory assertion, which seeks to determine whether a logical proposition or phenomenon is true or false, and the ontology of the command, which finds its expression in the imperative (Agamben 2019: 48). Philosophy and science are dominated by the first discourse, while the second discourse governs the fields of law, religion and magic. However, throughout Christianity and modernity, the ontology of the command has progressively displaced, 
marginalized and replaced the ontology of assertion (Ibid. 53). Consequently, the contemporary 'democratic' societies can be defined as:

societies in which the ontology of the command has taken the place of the ontology of assertion, yet not in the clear form of an imperative but in the more underhanded form of advice, of invitation, of the warning given in the name of security, in such a way that obedience to a command takes the form of a cooperation and, often, of a command given to oneself. (Agamben 2019: 53)

The new apparatuses of command do not only give prescriptions in the form of an invitation, as is the case with securitization, or in the form of seduction, as is the case with advertisement. These technological apparatuses can function because the subjects who are obeying the commands inscribed in these apparatuses believe to be in command (Ibid. 54). In other words, the 'free' subject of the neo-despotic imperative is a subject who obeys in the guise of commanding. She is ruled, governed and instrumentalized while she thinks she rules, governs and uses an apparatus.

What makes neo-despotism sinister is thus not merely its reliance on commands, but its ability to stage its commands as freedom of choice. The contemporary perversion of democracy resides, above all, in the consent to such choosing. Voting in elections and referendums, for instance, the main political activity today, has become a highly depoliticized practice in which people appear to freely choose while what to choose is really already suggested by the given political framework (Žižek 2018: 76). There is thus a repressive aspect to elections and referendums. As a mode of measuring 'opinion', they function as a 'grid' that frames and delimits our political perceptions (Deleuze 2006: 144). One possibility, in the face of the perversion of democracy, is thus subtraction or withdrawal, for instance in the form of abstention from voting (see Badiou 2008). Subtraction always implies a potential flight in relation to existing social determinations. Further, 
subtraction can function as a 'destituent power' (Agamben 1999: 255), which seeks to shift the focus of praxis from potentiality to impotentiality, from activity to passivity.

But what does destituent power mean in relation to the paradigm of voluntary servitude? Ancient despotism functioned on the basis of the slave's involuntary obedience. Early modernity, in turn, was awestruck by voluntary servitude. Machiavelli had portrayed servitude as a habitual phenomenon, as something people can become 'accustomed to' (2015: V). For Boétie, too, 'voluntary servitude' is a violence based on habitual consent (Boétie 2007: 113, 128)ç What we are witnessing today, in contrast, is the emergence of 'voluntary self-servitude,' the enslavement of the subject to its own will as a 'serf to no master but himself' (Baudrillard 2001: 61). Today's paradigmatic subject is its own despot, tyrannizing itself through strategies of self-control, normalization and discipline, trying to realize its potential, to turn itself into 'human capital,' and so on (Baudrillard 2010: 33). But while the slave internalizes the master, 'power also internalizes the slave who denies it, and it denies itself in the process' (Baudrillard 2010: 59). The result is, again, a neo-despotic power that feeds upon negating itself, a power which can only appear in the form of its disappearance. In this sense, populist figures like Le Pen and Trump 'unmask the truth of the system in their abuse of it' (Ibid. 39). By internalizing negativity, the neo-despotic power turns against itself. Neo-despotism, in this sense, designates the saturation of a power bent on 'realizing possibilities fully' (Ibid. 45). And so we come, once again, to a politics of deactivation.And any confrontation with a power that dictates the realization of potential calls for the juxtaposition of impotentiality to potentiality, free use to instrumental use. What is at stake here is the duality of use, the conflict between instrumental use and free use. Paradoxically, however, seen in the prism of instrumental use, free use often connotes sheer uselessness. The obsession with instrumental use obscures the use of the useless (art, philosophy, politics...), marginalizing all 
praxis that is not measurable in terms of utilitarian counting. Consequently, everywhere human life is put into (instrumental) use, the useless is appropriated by the useful.

This appropriation has three levels. First, one can appropriate activity (as, for example, labor power). Second, one can appropriate potential activity. On entering a securitized building, for instance, a fork would not be considered merely a fork but a potential instrument of terror and thus would be seized. What is seized here is not the fork as such, an instrument to eat with, but its potential use as a weapon (as well as, of course, its other potential uses). In a culture in which we are told to 'realize our potentials,' securitization functions as an apparatus to administer this imperative. And third, one can appropriate impotentiality or inoperatitivity. Consider the following ad for a recent version of smart phones:

The Light Phone 2 brings a few essential tools, like messaging, an alarm clock, or a ride home, so it's even easier to ditch your smartphone more often, or for good. It's a phone that actually respects you. (Quoted in Žižek 2018: 29)

What we have here is a peculiar negativity: the ad invites you to buy a phone not because of what it can do but because of what it does not do (tempting you into connecting to Facebook, Twitter...), the paradox being that you pay for some additional functions of the phone only in order to get rid of them (Ibid.). More interestingly, the phone turns use into a matter of contemplation. What the ad primarily seeks to sell is a capacity to contemplate impotentiality (rather than efficient use of potentiality). All apparatuses of capture need their lifeblood from the outside, from the domain of the useless. Like the 'accursed share,' however, free use is that which cannot be included within and thus challenges the reality principle of the world of instrumental reason. A world which denies recognizing free use, after all, can only be criticized, ridiculed or destroyed by free use, by demonstrating that beneath the despotism of the useful we always already have the use of the 
useless. Free use is a reminder that the real catastrophe is not uselessness but a world dominated by the useful alone.

\section{Conclusion: Neo-despotism, Use and Dissent}

Despotism, to conclude, appears in our political culture as that which cannot be symbolized, as what is 'out of place' in relation to its historical context. While it does not cut a 'normal' term in politics (no regime identifies itself with it and no regime identified so is considered 'normal' but rather 'rogue' etcetera), it comes into view either as an excrescent term (presenting itself in liberal democracies 'here' only in the manner of a specter, while its actual existence is projected onto the 'rogue' states 'there') or as a singular phenomenon (being present without being named as despotism, without formal existence in the socio-symbolic register). The recurring problem is, accordingly, a double reduction: time after time despotism is condensed to something unmeasurable and un-representable, on the one hand, or its persistent presence is denied, on the other. Therefore, I sought to articulate a measure of the despotic excess, illuminating the ways in which it persists despite being continuously overlooked or projected elsewhere. Freedom from despotism can only occur on the basis of recognizing despotism as despotism.

Yet, despotism is said in many ways. The classical literature understands despotism in its relation to economy and consent. In a counter-classical approach, though, the focus shifts to another triangulation: neo-despotism, use, and dissent. Thus a focus on neo-despotism as an instance of repetition casts the classical tradition in a new light, allowing us to revitalize the concept of despotism by putting it to a different use. However, there are common themes. For instance, it is fear, primarily the fear of dissent, that gives rise to both despotism and neo-despotism. Dissent is 
the foundation of every despotism. Further, in both, there is a contradiction between freedom, which is tied to free use, and voluntary servitude, which promises a freedom born of the fear of dissent. Nevertheless, voluntary servitude defines itself as freedom, just as neo-despotism misrecognizes itself as a democratic structure. But misrecognition itself is a perversion. Seeing oneself as the incarnation of the people is where the abuse of power, a function of misrecognition, begins.

Along the same lines, today consent functions, more visibly than ever, as an apparatus of instrumental use and thus abuse animated by technology. Automation, after all, is what happens when you achieve voluntary servitude. Voluntary servitude, in this sense, is a function of the system of counting, of a despotic account.

Only if one can opt out, suspend realizing one's potential, it seems, one can overcome the status of an automated being. Beyond instrumental use, after all, there is another meaning to life, the praxis of free use. Life, in free use, is a means without end. But is such a world prone to anarchy? Will human beings, left to their own, necessarily engage in an egoistic, destructive war of all against all? The problem with this question is what it hides: the fact that order itself is fundamentally anarchic. Thus, 'to the answer already contained in a question ... one should respond with questions from another answer' (Deleuze and Guattari 1987: 110). That other answer, in the horizon of this article, is free use. We need a new social theoretical language, which can force a reflection on the distribution of use vis-a-vis despotism, old and new. 


\section{References}

Agamben, G. (1998) Homo Sacer. Sovereign Power and Bare Life. Stanford: Stanford University Press.

Agamben, G. (1999) Potentialities. Collected Essays in Philosophy. Stanford: Stanford University Press.

Agamben, G. (2005) The State of Exception. Chicago: The University of Chicago Press.

Agamben, G. (2013a) 'For a theory of destituent power,' Public lecture, Nicos Poulantzas Institute, Athens, 16.11.2013, available at: http://criticallegalthinking.com/2014/02/05/theory-destituent-power/

Agamben, G. (2013b) Opus Dei. The Archeology of Duty. Stanford: Stanford University Press

Agamben, G. (2015a) The Use of Bodies. Stanford: Stanford University Press

Agamben, G. (2015b) Stasis. Civil War as a Political Paradigm. Edinburgh: Edinburgh University Press.

Agamben, G. (2019) Creation and Anarchy. The Work of Art and the Religion of Capitalism. Stanford: Stanford University Press.

Arendt, H. (1958) The Human Condition. Chicago: Chicago University Press.

Arendt, H. (1973) Origins of Totalitarianism. San Diego: Harcourt Brace \& Company.

Aristotle (1995) Politics. Oxford: Oxford University Press.

Badiou, A. (2009) Theory of the Subject. New York: Continuum.

Baudelaire, C. (2010) Paris Spleen. Richmond: Alma Classic Ltd.

Baudrillard, J. (2001) Impossible Exchange. London: Verso.

Baudrillard, J. (2007) In the Shadow of the Silent Majorities. London: Semiotext(e).

Baudrillard, J. (2010) The Agony of Power. Los Angeles: Semiotext(e).

Bauman, Z. (2017) Retrotopia. London: Polity.

Canetti, E. (1962) Crowds and Power. London: Phoenix.

Deleuze, G and Guattari, F. (1983) Anti-Oedious. Minneapolis and London: University of Minnesota Press. 
Deleuze, G and Guattari, F. (1987) A Thousand Plateaus. Minneapolis and London: University of Minnesota Press.

Deleuze, G. (2006) Two Regimes of Madness. Texts and Interviews 1975-1995. New York: Semiotex(e).

Diken, B and Laustsen, C.B. (2017) “'Life is a state of mind" - on fiction, society and Trump,' Journal for Cultural Research, Volume 21, pp. 257-267.

Foucault, M. (2001) Fearless Speech. Los Angeles: Semiotex(e).

Hobbes, T. (1991a). Leviathan. Cambridge: Cambridge University Press.

Hobbes, T. (1999) The Elements of Law Natural and Politic. Oxford: Oxford University Press.

Hobbes, T. (2007) Behemoth or the Long Parliament. London: Elibrion.

Keane, J. (2020) The New Despotism. Cambridge, Massachusetts: Harvard University Press.

Kundera, M. (2000) The Unbearable Lightness of Being. London: Faber \& Faber.

Machiavelli, Ni. (1999) Discourses Upon The First Ten (Books) of Titus Livy. http://www.constitution.org/mac/disclivy.pdf

Machiavelli, N. (2015) The Prince. Available at: http://constitution.org

Marx, K. (1970) Critique of Hegel's 'Philosophy of Right'. London: Cambridge University Press.

Marx, K. (1976) Capital. Volume I. London: Penguin.

Mitchell, D. (2015) 'Don’t ban Donald Trump. Just keep on laughing at him,' The Guardian, 13 December.

Newell, W.R. (2013) Tyranny. A New Interpretation. Cambridge: Cambridge University Press.

Nietzsche, F. (1974) The Gay Science. New York: Vintage.

Plato. (2003) The Republic. London: Penguin.

Plato. (2010) Statesman. Cambridge: Cambridge University Press.

Pocock, JGA. (2016) The Machiavellian Moment : Florentine Political Thought and the Atlantic Republican Tradition. New Jersey: Princeton University Press.

Rancière, J. (2003) The Philosopher and His Poor. London: Duke University Press. 
Rancière, J. (2006) Hatred of Democracy. London: Verso.

Schmitt, C. (1985) Political Theology. Four Chapters on the Concept of Sovereignty. Cambridge: The MIT Press.

Schmitt, C. (2004) The Theory of the Partisan: A Commentary/Remark on the Concept of the Political, by Carl Schmitt (Michigan State University Press.

Shakespeare, W. (1970) Macbeth. In The Complete Works of William Shakespeare. London: Spring Books, pp. $922-$ 945.

Spinoza, B. (1951a) A Theologico-Political Treatise. London: Dover.

Spinoza, Be. (1951b) 'A Political Treatise', in Spinoza, B (1951) A Theologico-Political Treatise. London: Dover, pp. 279-387.

Spinoza, B. (1993) Ethics. London: Everyman.

Vatter, M. (2014) Between Form and Event: Machiavelli's Theory of Political Freedom. New York: Fordham University Press

Virilio, P. (2012) The Administration of Fear. Cambridge: The MIT Press. Semiotext(e).

Xenophon. (1998) Oeconomicus. In Strauss 1998: 1-80.

Xenophon. (2013) Hiero. In The Complete Works of Xenophon, location 19712-20077. Hastings: Delphi Classics. Kindle Edition.

Žižek, S. (2001) Did Somebody Say Totalitarianism? London: Verso.

Žižek, S. (2017) The Courage of Hopelessness. London: Penguin.

Žižek, S. (2018) Like A Thief in Broad Daylight: Power in the Era of Post-Humanity. London: Penguin.

Bülent Diken is a professor in Social and Cultural Theory. He teaches in the Department of Sociology at Lancaster University and in the Department of Radio-TV and Cinema at Kadir Has University. His research fields are social theory, political philosophy, urbanism, cinema, and 
terrorism. His books include Strangers, Ambivalence, and Social Theory (1998), The Culture of Exception (2005, coauthored with Carsten B. Laustsen), Nihilism (2009), Revolt, Revolution, Critique - Paradox of Society (2012), God, Politics, Economy (2015), and The Cinema of Nuri Bilge Ceylan (2018, coauthored with Graeme Gilloch and Craig Hammond).

\footnotetext{
' I would like to thank Niels Albertsen, Shane Brennan, Michael Dillon and Floris Tomasini for very interesting discussions concerning the themes of this paper. Thanks also to the anonymous reviewers of Theory, Culture \& Society for insightful comments.

ii In the classical frame, the despotic rule refers to household management as an economic category, while tyranny signifies a political regime, albeit a perverted one. However, especially since the eighteenth century a displacement occurred and the two concepts have increasingly become synonymous, both signifying the perversion of regal power (see Grossrichard 1998). In the following, I use despotism and tyranny as synonymous, interchangeable concepts for what is crucial in the prism of this paper is their common denominator: the perversion of the political and the reduction of politics to economy.

iii See Keane 2020 for a different account of neo-despotism.
} 